\title{
Új, epicutan módszer az allergia oki kezelésére
}

\author{
Endre László dr. \\ Vasútegészségügyi Nonprofit Közhasznú Kft., Egészségügyi Központ, Budapest
}

\begin{abstract}
Az allergénspecifikus immunkezelés az allergia egyetlen oki kezelése. Injekciós és per os formái mellett legújabban epicutan módszer is ismert. Az immunizáció során az allergén mellett célszerú adjuváns anyagot is használni. Ilyen adjuváns anyag az alumínium-hidroxid és tirozin mellett baktériumtoxin is lehet. Ideális esetben a természetes allergén helyett célszerû annak olyan rekombináns változatát használni, amely allergenitását elvesztette, de immunogén sajátságát megőrizte. A jövő várható allergiakezelése a veszélytelen és fájdalommentes, epicutan módszerrel, rekombináns allergénnel és baktériumtoxin-adjuvánssal végzett hyposensibilisatio lehet.

Orv Hetil. 2017; 158(23): 895-899.
\end{abstract}

Kulcsszavak: allergiás betegségek, allergén-immunoterápia, immunológiai adjuvánsok, epicutan immunkezelés

\section{New - epicutaneous - method for the causal treatment of allergic diseases}

The only causal treatment for the allergic diseases is the allergen immunotherapy. Besides oral and injection forms, an epicutaneous form is known as well. During the immunization process the use of an adjuvant material is advisable besides the allergen. That adjuvant material can be (besides of the aluminium hydroxid and tyrosine) a bacterial toxin, too. In idealistic circumstances we can substitute the native allergen with its recombinant variant, which could keep its immunogenicity but had lost the allergenicity. In the future the recommended therapy could be the safe, painless, epicutaneous hyposensitization, with recombinant allergens, with bacterial toxin as adjuvants.

Keywords: allergic diseases, allergen immunotherapy, immunological adjuvants, epicutaneous immunotherapy

Endre L. [New - epicutaneous - method for the causal treatment of allergic diseases]. Orv Hetil. 2017; 158(23): 895-899.

(Beérkezett: 2017. március 20.; elfogadva: 2017. április 20.)

\section{Rövidítések}

AIT = allergén-immunterápia; $\mathrm{EKG}=$ elektrokardiográfia; $\mathrm{EPIT}=$ epicutan immunterápia; $\operatorname{IgE}=$ immunglobulin $\mathrm{E} ;$ IgG = immunglobulin G; IL = interleukin; $\mathrm{LT}=$ Escherichia coli baktérium hőlabil enterotoxinja; sc. = subcutan; $\mathrm{Th}=$ T helper

A világ népességének legkevesebb egynegyedét érintô idült betegség az allergia. Ennek leggyakoribb formája az allergiás nátha, amelynek prevalenciája hazánkban is legkevesebb 25\%. Tünetei enyhítésére kitúnő gyógyszerekkel rendelkezünk, de az oki kezelés egyetlen módszere az allergén-immunoterápia, amit az Európai és az
Amerikai Allergológiai Akadémia 2013-ban közzétett nómenklatúrajavaslata [1] előtt hyposensibilisatiónak neveztünk. Ennek lényege, hogy a tünetek kiváltásáért felelős allergént egészen kicsi adaggal kezdve, fokozatosan növekvő mennyiségben juttatjuk az allergiás egyén szervezetébe. Ennek hatására az allergia „megszűnhet”, pontosabban az allergiás egyén egyéb kezelés nélkül is tünetmentessé vagy legalább tünetszegénnyé válhat. $\mathrm{E}$ kezelésnek több formája ismert: bőr alá vagy izomba, esetleg nyirokcsomóba adott injekció, nyelv alatt elszopogatható tabletta vagy oldat és a jelen közleményben, a későbbiekben részletesen tárgyalandó epicutan módszer. Ennek az eljárásnak a történeti előzményei több mint 2000 évre nyúlnak vissza. 


\section{Történeti előzmények}

Plinius (a történetírás atyja) szerint a pontosi Mithridates király (i. e. 132-63) az akkoriban szokásos mérgezések elleni önvédelem céljából egyre növekvő adagú kígyómérget adott saját magának. Tulajdonképpen ezt tekinthetjük a hyposensibilisatiós kezelés első, írásban dokumentált leírásának. (Az már teljesen más lapra tartozik, hogy amikor a rómaiak elfoglalták a birodalmát, egy karddal ledöfte magát [2].)

A napjainkban is használt allergénspecifikus immunkezelést (a továbbiakban a nemzetközileg elfogadott AIT rövidítést használom) 106 éve írták le először. Nem lenne igazságos azonban, ha megfeledkeznénk ennek a forradalmian új kezelési eljárásnak az előfutárairól vagy legalábbis egyikükről, Bezredkáról. Ő Párizsban állatokat immunizált fokozatosan növekvő adagú allergénekkel, majd a kúra végén már akkora adagú allergént tudott reakciómentesen iniciálni nekik, amekkorától korábban anaphylaxiás sokkot kaptak. Ezt az eljárást antianaphylaxiás vakcinációnak nevezte el, s eredményeit 1907-ben közölte [3]. A mai napig „bezredkázásnak” nevezik az "öreg” allergológusok azt az eljárást, amelynek során aránylag rövid időközönként emelik a beadott allergéninjekciók adagját.

Feltehetően a fiatal Leonard Noon is olvasta ezt a közleményt és innét merítette a bátorságot, hogy hasonló eljárással szénanáthában szenvedő emberek esetében is megpróbálkozzon. Ehhez először kivonatokat kellett készítenie a pollenekből, majd azok különböző hígításaival bőrpróbát kellett végeznie, hogy kititrálhassa a kezdő adagot. A kezelés eredményét a kúra előtt és után a kötőhártyán (ugyanazzal az allergénkivonattal) végzett provokációval állapította meg. Kedvező eredményeit először 1911-ben, a Lancetben publikálta [4]. Sajnos nagyon fiatalon, tuberkulózisban meghalt.

A tudomány és a betegek szerencséjére módszere nem merült a feledés homályába, mert kollégája, John Freeman folytatta az eljárást és még ugyanabban az évben (ugyancsak a Lancetben) nagyobb számú betegen szerzett kedvező tapasztalatairól tudott beszámolni [5].

1911 után ez az eljárás gyorsan elterjedt, és 1914-ben Robert Cook (aki az „atopia” szót kitalálta) már az Amerikai Egyesült Államokban is használta [6]. Ő javasolta e kezelés leírására a hyposensitisatio kifejezést.

Az első, mai szemmel is modernnek mondható (kontrollkezelésben részesülő betegeket is bemutató) közleményt William Frankland publikálta az Allergy akkori elődjében, az Acta Allergologicában 1955-ben [7].

A hozzáférhető adatok szerint Magyarországon az első AIT-kezelésról Hajós Károly és leánya számolt be a Magyar Belorvosi Archivumban 1966-ban [8].

Jelen sorok szerzője pedig (mint orvostanhallgató) abban a boldogságban részesülhetett, hogy életében legelőször (és mindjárt az Orvosi Hetilapban!) éppen egy AIT-ról beszámoló közleményben olvashatta - társszerzőként - nyomtatásban a nevét [9].
Az AIT 1911-ben történt első leírása óta szinte állandóan próbálkoztak a kezelés hatásfokának növelésével és az anaphylaxiás reakció esélyének csökkentésével.

\section{Adjuváns anyagok szerepe az immunizációban}

Az már csaknem 100 éve ismert, hogy jobban lehet immunizálni a kísérleti állatokat, ha az allergén mellett valamilyen adjuvánst is használunk. Erre teljesen véletlenül 1924-ben két angol kutató jött rá. Azt figyelték meg, hogy a tuberkulózisban szenvedő tengerimalacok több ellenanyagot tudtak termelni egy adott allergéninjekció hatására, mint az egészségesek [10].

Néhány évvel később Dienes (North Carolinában) felismerte, hogy elölt tbc-baktériumokkal ugyanezt a hatást lehet elérni [11].

Jules Freund volt az első, aki az elölt tbc-bacilust valamilyen olajjal együtt használta adjuvánsként. Katherine McDermottal 1942-ben írott közleményükben [12] részletesen ismertették az általuk használt adjuvánst és a vele (tengerimalacokon) elért kiváló eredményt.

Körülbelül ez idő óta tudjuk, hogy a több mint 100 éve ismert AIT injekciós formájában érdemes valamilyen adjuvánst is használnunk. Az 1970-es években ez többnyire alumínium-hidroxid, később tirozin lett. Ezek nem csupán az adott allergén immunitását fokozták, hanem az injekció felszívódását is lassították.

Glenn és mtsai 1999-ben felfedezték, hogy immunizálás során az adjuváns anyag baktériumtoxin is lehet [13].

\section{Immunizálás a bőr felszínéről}

Azt, hogy bőrön keresztül is lehet immunizálni, Glenn és mtsai írták le elsóként 1998-ban, a Nature-ben [14].

2000-ben 18 önkéntes felnőtt embert Escherichia coli hőlabil enterotoxinjával (a továbbiakban: LT) az általuk felfedezett epicutan (EPIT) módszerrel immunizáltak. Azt tapasztalták, hogy $500 \mu \mathrm{g}$ LT háromszori felvitelével a vizsgált egyének LT-ellenes lgG szintje átlagosan a kiindulási érték 14,6-szeresére, míg az LT-ellenes IgA szintje 7,2-szeresére emelkedett. Ez a magas ellenanyagtiter legkevesebb 35 hétig megmaradt [15]. A következő években módszerüket továbbfejlesztették [16-19]. Azt is ők írták le elsőként (2007-ben), hogy az immunválaszt tovább lehet fokozni, ha a bőr legfelső rétegét (a stratum corneumot) valamilyen módszerrel elvékonyítják [16]. A bőr előkezelésének standardizálására egy speciális (általuk skin prep systemnek elnevezett) készüléket is szerkesztettek [17].

\section{Hyposensibilisatio a bőr felszínéről}

Az EPIT-módszer forradalmi újdonságát felismerve, elsőként svájci kutatók próbálták vele a légúti allergiát mérsékelni [20]. E kísérletükhöz az elméleti alapot az 
jelentette, hogy a bőrben sok dendritikus és Langerhanssejt van, amelyek „hivatásos” antigén-bemutató sejtek. Ők 1,5 ml vazelinben kevertek el 300 egység Phleum pratense füallergén-kivonatot és ezt ragasztották fel légmentesen 48 órára a páciensek bőrére. Ezt egyhetes időközökkel négyszer ismételték a füpollenszezon előtt. (A vazelinen kívül egyéb adjuvánst nem használtak.) 21 en aktív kezelést, 16-an placebót kaptak. A kezelésben részesülteknek a „szénanáthás” klinikai tünetei erősen szignifikánsan enyhébbek lettek a placebocsoportba tartozókénál, még a kezelést követő második évben is ( $\mathrm{p}=$ $0,005)$, és a nasalis provokációjuk is sokkal kedvezőbb képet mutatott $(\mathrm{p}<0,001)$.

Azt, hogy ez a módszer a jövő új, fájdalommentes és biztonságos kezelési lehetősége lehet, a Journal of Allergy and Clinical Immunology szerkesztősége is felismerte, mert nagyon szép méltatást írt közvetlenül e cikk után [21].

Ugyanez a svájci munkacsoport 2015-ben az Allergyben ismertette további ez irányú vizsgálatuk kedvező eredményét [22]. 48 rhinoconjunctivitises beteg (a bőr ragasztószalagos előkezelése után) egyhetes időközökkel hatszor, egy-egy alkalommal nyolc órán keresztül kapott 200 IR füpollenkivonatot $1,5 \mathrm{ml}$ petrolatumban (míg az 50 „placeboegyén” csak petrolatumot). A kezelés évében a klinikai javulás 48\%-os volt, és még a következő évben is $40 \%$-os maradt, míg a placebót kapók között ez az arány a $10 \%$-ot is alig érte el.

\section{Rekombináns allergénekkel végzett AIT}

A kezdetektől használt természetes allergénkivonatok hátránya, hogy rengeteg fajta anyagot tartalmaztak, olyanokat is, amelyekre a kezelt egyén nem is volt allergiás.

$\mathrm{Az}$ allergének szerkezetét megismerve kiderült, melyek azok a peptidek, sőt molekulaszakaszok, amelyek az allergiás reakciót okozzák, és melyek azok, amelyek immunogének, azaz, amelyek az allergia megszűnését segítik elő. Mindezek ismeretében logikusnak tünt, hogy egyrészt olyan tisztított allergéneket állítsanak elö, amelyek kizárólag azt a peptidet tartalmazzák, amelyik felelős az adott allergiáért, sőt ha lehetséges, ezt a peptidet úgy módosítsák, hogy az immunogén tulajdonságát megtartsa, de az allergenitását veszítse el [23].

Az 1980-as évek végére sikerült először elóállítani géntechnológia segítségével tiszta formában rekombináns allergéneket.

Valamilyen rekombináns allergénnel emberen történó AIT első írásos közlése 1998-ból, Mueller és munkatársaitól származik [24]. Ök a méhméreg legfontosabb allergénjéból, az API ml-ból származó három rövid peptid keverékével végeztek kezelést méhcsípésre allergiás egyéneken, és öt betegük közül három toleránssá vált reális - méhcsípéssel történő - provokációban.

Ezt követően állatkísérletekben beigazolódott, hogy elő lehet állítani olyan hipoallergén formákat is, amelyeknek csökkent az IgE-kötő kapacitása, T-sejt-epitopokat tartalmaznak és IgG-ellenanyag-termelést váltanak ki [25].

Megfigyelték, hogy a komplett (természetes) allergénnel szemben toleranciát lehet kiváltani azzal az allergénből kivágott peptiddel, amelyet az allergénspecifikus T-sejt felismer. Macskaallergia esetén már klinikai vizsgálatok is folytak ilyen T-sejt-epitopokkal történő immunizációval, de, sajnos, nem IgE által közvetített nemkívánatos mellékhatások itt is előfordultak [26].

Rekombináns technológiával úgy próbálnak meg hipoallergén-változatot elóállítani, hogy valamilyen mutációval vagy deletióval megváltoztatják az allergén térszerkezetét az IgE-t megkötő B-sejt-epitop környékén. Ez például „lisztatka”, nyírfa-, olajfa- és füpollen esetében már megtörtént. Néhány tucat allergiás betegen már teszteltek is ilyen hipoallergén-variánsokat, és például a nyírfapollen Bet vl fragmentjével végzett bőrpróba során akár ezredrészére csökkent allergénaktivitást észleltek [27].

\section{Rekombináns allergénnel és baktérumtoxin-adjuvánssal végzett EPIT-kezelés}

Az Allergy 2017. januári számában szerkesztőségi közlemény jelent meg egy egészen újfajta EPIT-módszerü kezelésről [28].

Ennek apropóját a Bécsben dolgozó Rudolf Valenta munkacsoportjának a dolgozata szolgáltatta. E munkában három újdonságnak a világon elsőként történő öszszekapcsolásáról számolnak be. Egyrészt EPIT-módszert, másrészt rekombináns allergént, harmadrészt adjuvánsként baktériumtoxint használtak [29].

Állatkísérletükhöz (szándékosan) nehezen immunizálható beltenyésztett felnőtt tengerimalacokat választottak. Az EPIT-módszerú immunizációt az 1., a 15. és a 28. napon végezték. Adjuváns anyagként a már többször említett LT-t, míg allergénként az általuk előállított kétfajta (az egyik a komplett „összehajtogatott” molekula volt, a másik a „hajtogatás” nélküli) rekombináns nyírfapollent (rBet v l) használták. A bőrrel érintkező felület $2,85 \mathrm{~cm}^{2}$ területű volt és az allergént legkevesebb 12 óra hosszat hagyták az előkezelt bőrön, légmentesen leragasztva. Kontrollként alumínium-hidroxidhoz kapcsolt allergénnel sc. injekciókat adtak.

Azt találták, hogy az alumíniumhoz kapcsolt allergénnel sc. immunizált állatok és az LT-vel plusz komplett allergénnel immunizáltak egyaránt termeltek allergénspecifikus IgG-t. Azt, hogy a termelt $\lg$ G valóban allergénspecifikus, úgy igazolták, hogy nyírfapollen-allergiában szenvedő emberek véréből származó $\operatorname{lgE}$-t meg tudta gátolni abban, hogy az a Bet v 1 allergénhez kapcsolódjon. Korábban (embereken) elvégzett vizsgálatuk során azt tapasztalták, hogy a kizárólag nagy adagú ( $160 \mu \mathrm{g} /$ patch) Bet v l-gyel (tehát LT nélkül) EPITmódszerrel kezelt emberek allergénspecifikus T-sejt-vá- 
laszt mutattak ugyan, de nem termeltek allergénspecifikus IgG-t. Úgy gondolják, hogy az LT valószínúleg direkt stimulálja a B-sejteket, mégpedig úgy, hogy hatására tovább marad az allergén intakt állapotban (fontos, hogy intakt állapotban, ezért nem volt hatásos az „összehajtogatás” nélküli rekombináns pollenallergén) az antigént bemutató sejt felszínén és így lehetősége lesz a B-lymphocytának, hogy felismerje az allergént, és plazmasejtté átalakulva IgG típusú blokkoló ellenanyagot termeljen ellene.

Az AIT-kezelés lényege, hogy az allergiára jellemzô Th2-lymphocyta-túlsúly megszúnik, a Thl-es sejtek lesznek a dominánsok, ugyanígy a citokinprofil is megváltozik, fokozódik az IL-2, IL-15 és interferon-gammatermelés, ami viszont meggátolja az IgE-termelést elősegítő IL-5 szekrécióját. Mindezek hatására (átmenetei emelkedés után) csökken az allergénspecifikus IgE-koncentráció és nő a blokkoló, allergénspecifikus lgG4 szintje. (Ezt az osztrák szerzők most ismertetett állatkísérletükben igazolni is tudták.)

Végső megállapításuk, hogy az LT egy EPIT során még nagy adagban is biztonságosan használható, nagyon jó adjuváns [29].

Az EPIT azért lehet ennyire eredményes, mert a bőrben rengeteg antigén-bemutató (például Langerhans- és dendritikus) sejt van, másrészt a stratum corneumban egyáltalán nincsenek erek, így az általános (anaphylaxiás) reakció veszélye nagyon kicsi.

Mivel napjainkban a népességnek legkevesebb egynegyede szenved légúti allergiában és az allergia egyetlen oki kezelése az AIT, nem kell nagy képzelőerő ahhoz, hogy megjósoljuk: a rekombináns allergénekkel és LTvel, mint adjuvánssal végzett EPIT-kezelések a jövő ígéretes eszközei lesznek. A hazánkban utoljára 2004-ben publikált, nagyon részletes és kiválóan használható szakmai ajánlás ezt az eljárást természetesen még nem népszerüsíthette, mivel abban az időben még csak a subcutan és sublingualis allergénbeviteli formák voltak ismertek [30].

Anyagi támogatás: A közlemény megírása anyagi támogatásban nem részesült.

A szerző a cikk végleges változatát elolvasta és jóváhagyta.

Érdekeltségek: A szerzőnek nincsenek érdekeltségei.

\section{Irodalom}

[1] Calderon MA, Casale T, Cox L, et al. Allergen immunotherapy: a new sematic framework from the European Academy of Allergy, Asthma and Immunology/PRACTALL Consensus report. Allergy. 2013; 68: 825-828.

[2] Ring J, Gutermuth J. 100 years of hyposensitization: history of allergen-specific immunotherapy (ASIT). Allergy. 2011; 86: 713-724.
[3] Bezredka A. Du mecanisme de l'anaphylaxie vis-a-vis du serum de cheval. C R Soc Biol. 1907; 59: 294-296.

[4] Noon L. Prophylactic inoculations against hay fever. Lancet. 1911; 178: 1572-1573.

[5] Freeman J. Further observation on the treatment of hay fever by hypodermic inoculations of pollen vaccine. Lancet. 1911; 178: 814-817

[6] Cooke RA. The treatment of hay fever by active immunization. Laryngoscope. 1914; 25: 108-112.

[7] Frankland AW. High and low dosage pollen extract treatment in summer hay fever and asthma. Acta Allergol. 1955; 9: 183-187.

[8] Hajós K, Hajós M. Allergology and iatrogen damages. [Allergológia és iatrogen ártalmak. Magy Belorv Arch. 1966; 39: 264271. [Hungarian]

[9] Osváth P, Endre L. Treatment of asthmatic children with a vaccine (Allpyral) containing aluminum hydroxide-absorbed extract. [Asthma bronchialés gyermekek kezelése aluminiumhydroxidhoz adszorbeált kivonatot tartalmazó (Allpyral) oltóanyaggal.] Orv Hetil. 1969; 110: 1549-1551. [Hungarian]

[10] Lewis PA, Loomis D. Allergic irritability. The formation of antisheep hemolytic amboceptor in the normal and tuberculous guinea pig. J Exp Med. 1924; 40: 503-515.

[11] Dienes L. Further observations conceming the sensitization of tuberculous guinea pigs. J Immunol. 1928; 15: 153-174.

[12] Freund J, McDermott K. Sensitization to horse serum by means of adjuvants. Proc Soc Exp Biol Med. 1942; 49: 548-553.

[13] Glenn GM, Scharton-Kersten T, Vassell R, et al. Transcutaneous immunization with bacterial ADP-ribosylating exotoxins as antigens and adjuvants. Infect Immun. 1999, 67: 1100-1106.

[14] Glenn GM, Rao M, Matyas GR, et al. Skin immunization made possible by cholera toxin. Nature. 1998; 391: 851 .

[15] Glenn GM, Taylor, DT, Li X, et al. Transcutaneous immunization: A human vaccine delivery strategy using a patch. Nat Med. 2000; 6: 1403-1406.

[16] Glenn GM, Villar CP, Flyer DC, et al. Safety and immunogenicity of an enterotoxigenic Escherichia coli vaccine patch containing heat-labile toxin: use of skin pretreatment to disrupt the stratum comeum. lnfect Immun. 2007; 75: 2163-2170.

[17] Glenn GM, Flyer DC, Ellingsworth LR, et al. Transcutaneous immunization with heat-labile enterotoxin: development of a needle-free vaccine patch. Expert Rev Vaccines. 2007; 6: 809819.

[18] McKenzie R, Bourgeois AL, Frech SA, et al. Transcutaneous immunization with the heat-labile toxin (LT) of enterotoxigenic Escherichia coli (ETEC): Protective efficacy in a double-blind, placebo-controlled challenge study. Vaccine. 2007; 25: 36843691.

[19] Frech SA, DuPont HL, Bourgeois AL, et al. Use of a patch containing heat-labile toxin from Escherichia coli against travellers' diarrhoea: a phase II, randomised, double-blind, placebo-controlled field trial. Lancet. 2008; 371: 2019-2025.

[20] Senti G, Graf N, Haug S, et al. Epicutaneous allergen administration as a novel method of allergen-specific immunotherapy. J Allergy Clin Immunol. 2009; 124: 997-1002.

[21] Werfel T. Epicutaneous allergen adminstration: A novel approach for allergen-specific immunotherapy? J Allergy Clin Immunol. 2009; 124: 1003-1004.

[22] Senti G, von Moos S, Tay F, et al. Determinants of efficacy and safety in epicutaneous allergen immunotherapy: summary of three clinical trials. Allergy. 2015; 70: 707-710.

[23] Pauli G, Malling HJ. The current state of recombinant allergens for immunotherapy. Curr Opin Allergy Clin Immunol. 2010; 10: 575-581.

[24] Mueller U, Adkis CA, Fricker M, et al. Successful immunotherapy with T-cell epitope peptides of bee venom phospholipase A2 induces specific $\mathrm{T}$-cell anergy in patients allergic to bee venom. $\mathrm{J}$ Allergy Clin Immunol. 1998; 101: 747-754. 
[25] Vrtala S, Focke-Tejkl M, Swoboda I, et al. Strategies for converting allergens into hypoallergenic vaccine candidates. Methods. 2004; 32: 313-320.

[26] Oldfield WL, Larché M, Kay AB. Effect of T-cell peptides derived from $\mathrm{Fel} \mathrm{d} \mathrm{l}$ on allergic reactions and cytokine production in patients sensitive to cats: a randomized controlled trial. Lancet. $2002 ; 360$ : 47-53.

[27] Pauli G, Purohit A, Ostep JP, et al. Comparison of genetically engineered hypoallergenic $\mathrm{rBet} \mathrm{vl}$ derivatives with $\mathrm{rBet} \mathrm{vl}$ wildtype by skin prick and intradermal testing: results obtained in a French population. Clin Exp Allergy. 2000; 30: 1076-1084.

[28] Killingbeck SS, Ge MQ, Haczku A. Patching it together: epicutaneous vaccination with heat-labile Escherichia coli toxin against birch pollen allergy. Allergy. 2017; 72: 5-8.
[29] Cabauatan CR, Campana R, Niespodziana K, et al. Heat-labile Escherichia coli toxin enhances the induction of allergen-specific $\operatorname{lgG}$ antibodies in epicutaneous patch vaccination. Allergy. 2017; 72: 164-168.

[30] Cserháti E, Adonyi M, Barkai L, et al. Allergen specific immunotherapy in pediatric patients. [A gyermekkori specifikus allergén immunterápia: Allergén vaccinatio - módszertani ajánlás.] Gyógyszereink. 2004; 54: 37-49. [Hungarian]

(Endre László dr., Budapest, Podmaniczky u. 109., 1062 e-mail: endrelaszlo@freemail.hu)

\section{TÉVESZMÉEK AZ ALTERNATIV GYÓGYÁSZATBAN?}

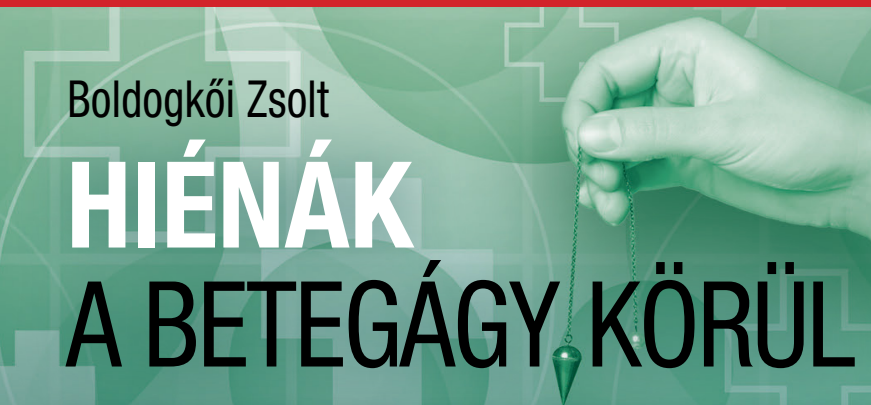

A szerzó molekuláris biológusként elszántan küzd az áltudomány és a beteg ember kiszolgáltatott helyzetét kihasználó „kuruzslás” ellen. Könyvében a következő kérdéseket veti fel, állásfoglalása egyértelmü:

- Van-e tudományos alapja az íriszdiagnosztikának, homeopátiának, lúgositásnak, energiamezőknek?

- Miért csökken a tudományos gyógyítás presztízse, míg az alternativ gyógyitás népszerüsége egyre nő?

- Hogyan mérhető a terápia, a diéta hatása, miért hisznek a betegek csodaszerekben?

- Miért hajlandók sokan komoly összeget áldozni kétséges hatású terápiákra, szerekre, gyógyhatású készítményekre?

320 oldal, 3400 Ft • világraszóló tudás • www.akademiaikiado.hu
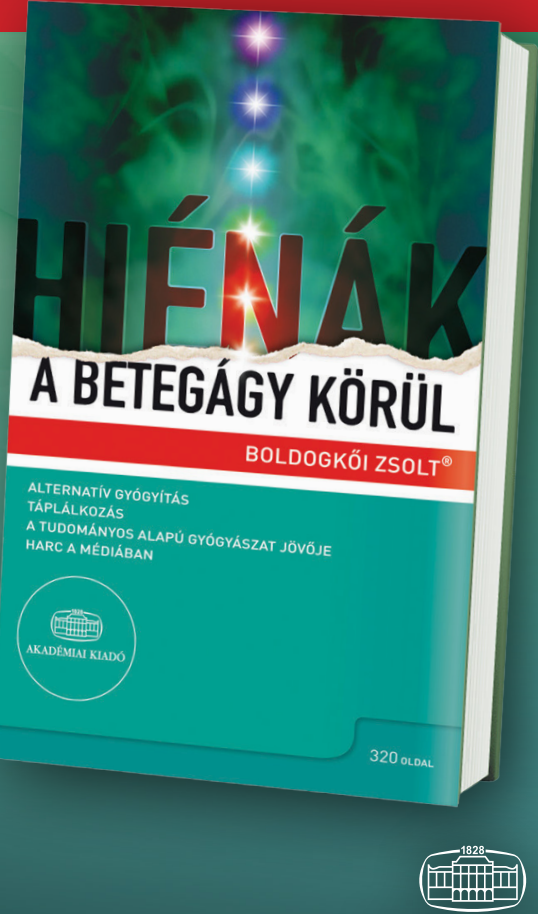

AKADÉMIAI KIADÓ 